wod kearne were there, and they answered not in three days before. It was asked of them whether they would have meat or money to relieve them; they answered both meat and money; so the governor commanded to collect a proportion of victuals from among the soldiers' knapsacks, and left it with them, and so departed and went on his journey.

Also in this year, for the quietnes of the kingdom of Ireland, and for the better appeazinge of strife, contentions, and sutes in lawe in time to come amonge the inhabitantes of the land, it hath bene ordered and agreed by grave advice, with the consent of the Quenes majestie and councells of boathe kingdoms, that theare should be established in Ireland an acte of oblivion, wheareby all sutes, bills, complaintes and all former challenges whatsoever before this year 1602, for any stealthes, robberies, preys taking, or any suche like thing done in the time of rebellion should cease, and be no more thought upon for ever, those sutes only excepted which had bene formerlie commenced by orderlie course of lawe, (before that time specified) and had been put in sute before the judges of anie hir Majesties highe courte of record, or otherwise determyned upon, by way of arbiterment with the consent of boathe parties.

(To be continued.)

\title{
An Unpublished Political Paper by Daniel De Foe.
}

THE interesting document which follows is included among a miscellaneous collection of historical and other papers in the Lansdowne MIS. 98 in the British Museum (ff. 223-246). It is without title, signature, or date, but is indorsed in a somewhat later hand, 'Maxims and Instructions for Ministers of State, seemingly written about the end of the reign of $Q$. Anne for the use of some great man.' The actual date is some years earlier, but otherwise this description is correct enough, and, except that the last seven words are omitted and 'by some very able statesman' put in their place, it is substantially repeated in the catalogue of the Lansdowne MSS. published in 1819. Hitherto, however, so far as I can ascertain, the contents have altogether escaped notice. This can only be accounted for by the absence of the anthor's name, and yet the clue to his identity lay all the time literally on the surface. The loss of the covering letter, which no doubt once existed, is in fact immaterial, for the handwriting can be recognised at a glance as that of Daniel De Foe ; and not only does internal evidence also point to him as the author, but, without going further than the second paragraph, it is equally clear that he was addressing Robert Harley, shortly after the latter became secretary of state on 18 May 1704.

Since the publicaiion by the Historical Manuscripts Commission 
in 1897 of vol. iv. of the Portland Papers it has been known that there were close political relations between the two during the whole time that Harley was in power. They apparently began while De Foe was in Newgate Prison, to which he was committed in July 1703 for publishing his famous ironical pamphlet T'ke Shortest Way with the Dissenters, and it was through the influence of Harley, then Speaker, who was shrewd enough to see the use that might be made of his peculiar talents, that he was released early in November. The gratitude effusively expressed in his subsequent letters among the Portland Papers, beginning with one of 9 November, was no doubt perfectly sincere; at the same time, he evidently had a lively expectation of favours to come, and after a few months' interval, during which Harley had taken office, he appears as a paid secret agent of the government. In this communication, however, he plays the more dignified part of a political Mentor and takes upon himself to instruct his new patron with the utmost freedom on the course he ought to pursue in order to secure popularity with all parties and ultimately attain the position of an all-powerful prime minister of the type of Richelieu, Mazarin, or Colbert. His advice to that end and his observations in general are marked by his usual practical sagacity, showing an intimate knowledge of affairs and a keen insight into the character of the man with whom he had to deal; they are expressed also in the clear, incisive, and perfectly straightforward language of which he was a master, and it is only with regard to the plan proposed by him for conciliating the dissenters that he seems apprehensive of being charged with duplicity. Interesting as it would be to trace how far Harley's future policy was in accord with the principles laid down for him, there is no room for such an inquiry here; but in one direction De Foe's arguments appear to have had an immediate effect. As will be seen, he lays special stress upon the necessity for a regular system of collecting intelligence from all quarters, in order that the government might be kept informed of the state of feeling in the country and steps might be taken to counteract adverse influences; and his own employment for this purpose, for which his restless energy and quick wit admirably qualified him, was no doubt a direct consequence of his advice. A letter from him to Harley of 28 September $1704^{\prime}$ proves that he was then busily at work in the eastern counties, and he was appas rently starting on a mission of some kind in the previous July." 'The present paper, in which he speaks of Harley's 'new post,' was therefore probably drawn up in May or June ; in any case its date must be before 2 November, for in writing to Harley on that day ${ }^{3}$ he evidently refers to it when reminding him of what he had

\footnotetext{
' Portland Papers, iv. $136 . \quad$ :Ibial. p. $106 . \quad{ }^{3}$ Ibid. p. 147.
} 
formerly written on the subject of Richelieu. Although it begins rather abruptly, the paging, which appears to be original, shows that nothing except the covering letter is wanting.

G. F. W

I allow that in our constitucion we admit of no supreme ministry ; that the nacion is perticularly jealous of Favourites. These are the two chief obstruccions in the way of a refin'd and riseing statesman, and these are the two reasons why we have had no capitall men in the civill administracion, no Richlieus, Mazarines or Colberts in the state. But I must go back for a reason for these two principles, and must say : 1. It wou'd be best to have a supreme ministry: 2. The nacion may easily be reconcil'd to it. Twill be needless to prove the advantage of a chief ministry ; our confusions in council, our errors in execcuting and unwaryness in directing from the multitude and bad conduct of ministers make it too plain. To prove the nacion may be easily reconcil'd to it, twill be needfull to go back for the reasons why former favourites have so. ill pleas'd the nacion, and how others have discharg'd themselves with honour. The Spencers, the Gavestones of former reigns are too remote; the prime ministers of modern times have been principally the Earle of Leicester, the [Duke] of Somersett, Buckingham, etc. These all incur'd the displeasure of the people by one crime, persueing their private intrest, enriching and aggrandizeing themselves and familyes, and raiseing vast estates out of the spoils of the publick, and by their Princes favour heaping up honours and titles to themselves from mean originalls. I need not search hystory for the perticulars, the fact is too plain. The consequences of this spirit of covetousness were allways extorcions, oppressions, bribes, sale of publick employments, intrenchments on the publick moneys, exorbitant grants of Royal bounty, and the like. If any man will sho' me the man that serv'd the state abstracted from his own. intrest, he shows them (sic) the man who was as much the peoples favourite as the kings. Tho: Lord Cromwell was such a one, and, tho' he fell, as. who in the reign of that fickle, unconstant king could stand, he fell a sacrifize to the Protestant party, universally belov'd and lamented of the people. Sir Francis Wallsingham, tho' not a prime minister, yet, if we read his story, the ablest statesman and the longest employ'd, the most. employ'd in difficult cases and the greatest master of intelligence in the age, [was such another]. Both these dyed poor, they spent their wholl time in the service of their country, and no man would ha' repin'd at. their enjoying their Princes favour longer.

This premis'd I bring home the matter to the case in hand. How shall you make yourself Prime Minister of state, unenvy'd and unmolested, be neither address'd against by Parliament, intreagu'd against by partyes, or murmur'd at by the mob ? With submission tis very feasible with an accurate conduct. They say those designs require most policy which. have least of honesty; this design must be honest, because it must be honest to serve our country. If it be objected, 'But I wou'd not be Prime Minister,' I returne, 'Then you can not be Secretary of State.' The Secretaryes office well discharg'd makes a man Prime Minister of course; 
and you must be Prime Minister with applause, or you will be Secretary with disgrace. Popular fame never thinks a man too high, popular hate never thinks him too lowe. A generous, free, noble, uncontracted conduct as effectually secures the affeccion of the people, as a narrow, covetous, craveing spirit effectually engages their mortall aversion. Tis certainly a noble design to be popular from a principle of reall meritt. I observ when all our people clamourd at Dutchmen, and even the king cou'd not please them, because he was a forreigner, no man ever had a bad word for Mons ${ }^{r}$ Overkirk. Nothing wins this nacion like generous, free, openhanded courtesye. The King of Sweden in his German warrs allwayes employ'd trusty persons in the towns and cittyes he reduc'd, to inform themselves of any known case where one was oppress'd, or any family that had the generall pitty ; and unlook'd for, unask'd, he would send for, right, and reliev them. Sir, that noble soul is a rare pattern; he gain'd his very enemyes by surprizeing acts of bounty. In your new post, joyn'd with the influence you have on the royall hand, you will have infinite opportunitys to fix an invulnerable reputacion. May not these heads be proper?

1. To keep a sett of faithfull emissarys selected by your own judgement; let them be your constant intelligencers of private affaires in the Court.

2. Sett your friends by, if they are such they'l wait, but surprize your enemyes, if you have any, with voluntary kindness.

3. Communicate your favours with unbyast hand, that all partyes may court you.

4. You have estate enough, and honour enough. Let the world kno' you covet nothing; all men then will covet you.

Let no man under you make a profitt of your favours. One Gehezai in your attendants, will undo the merit of all your accions; he will gett the money, and you the curse of the person that payes it. Tis absolutely necessary to be popular. The peoples darling may be a few mens envy, but the peoples hate is a statesmans ruin. This opinion of the people is easily gain'd at first, and if lost at first, never reestablish'd. Tis gain'd by litle acts of courtisy ; one generous man oblig'd, one oppresst man reliev'd, does a man of trust more honour than twenty ill tongues can blott out. In order to this, your trusty servants will enquire you out occasions enough [for] a generall forwarding and dispatch of peticions, and a thousand things which a man in such a post, with such a soul, never wants opportunity for. In the old Prince of Oranges ${ }^{4}$ army a captain that had long serv'd in the warrs, talking to a friend, was heard to say he would give 10000 guilders for such a regiment, the collonell being newly dead. 'Why do you not put in for it,' sayes his friend. 'Because,' saies he, ' the Prince has no kindness for me, and I kno' he will denye me.' The Prince, knowing him to be a man of meritt, sends the person who told him this story with orders to take his bond for the 10000 guilders upon condicion that he procur'd him the regiment, which he did accordingly. The next day the Prince sends for him, gives him the regimente, and as he was goeing out, 'Here,' says the Prince, ' and here's something for your equipage,' and threw him his bond. The man was so surprized with the

- 'Maurice' written on the blank page opposite. 
generosity of it, he turn'd from a prejudic'd person to the greatest admirer the Prince had.

Sir, this proposall of a generous bounty and courtisye is not directed because you want it, but because you have it. To suppose you want it wou'd first be an insolence unpardonable, as it would propose your feigning it, and so make a vertue of hypocrisy; but, as I have more than ordinary proofs of your being master of the quallity, I take the freedome to hint the uncommon advantage it gives you, to make your self truly great and have all men pleas'd with it. Envy allwayes goes with her mouth open, and you are not to expect that an advanc't post will shut it; but there is a secret in mannagement that checks it effectually, viz. a generall unaffected goodness of temper. Julius Caesar was remarkable for it, and conquer'd more enemyes in the forum than in the field. A man can never be great that is not popular, especially in Fingland. Tis absolutely necessary in the very nature of our constitucion, where the people have so great a share in the govornment. Besides, the people lere, in recovering their just rights, have usurpt some that are not their due, viz. censuring their superiours. But the govornment is bound to submit to the grievance, because tis incurable. Tis true a wise man will slight popular reproach, but no wise man slights the generall approbacion, because nothing but vertue can obtain it. Tis therefore absolutely necessary for a states man to be popular. A states man once in the peoples favour has a thousand opportunityes to do with freedome what in a contrary circumstance be would not dare to attempt; for as the people often condemne hastily, they approve with more blindness than they censure, and yet, generally speaking, the common people have been allwayes in the right. A states man envy'd dares not attempt a thing which he knows is for the publick service, least the miscarriage falls upon himself. Cardinall Richlieu supply' $c$ the want of the peoples favour by meer force and so ruin'd those that oppos'd him, as in the case of the Duke de Momorency and a multitude of others. Tho' this would be impracticable here, it showes the absolute necessity of the ling, or of an equivalent. And yet we find this Cardinall strove hard for the publick voice and us'd a thousand artifices to obtain it; among which this was one, that he never appear'd to his own resentments and, tho' a multitude of persons of all ranks were sacrifiz'd to his politick interest, yet he never would be seen in a matter of punishment. If a pardon was to be granted, he took care the débt should be to the Cardinall, but, if justice was to be done, that was in the King. A popular states man shou'd have the obtaining all the favours and let others have the mannagement of offences and the distribucion of justice.

In your perticular case, Sir, you have but one publick misfortune, viz. that your friends for want of judgement are aftiraid of you, not affraid you'l hurt them but yourself. Twou'd be necessary to confirm them in the belief of all they hope to find.

No. 1. A Perticular step will absolutely effect it-of which by itself.

No. 2. A scheme of what I mean by popularity in your own perticular, and how to be both obtain'd and improv'd for the publicl service, shall be drawn, if you please to admitt it.

No. 3. Also a method to make the office of Secretary of State an inner 
cabinett, and execute necessary parts of private afiaires without the intervencion of the Privy Council, and yet have their concurrence as far as the law requires.

When a Prince is to act anything doubtfull or any thing likely to be disputed either at law or in Parliament, the Council is a necessary screen to the Secretaryes of State. But in matiers of war, treatys, embassys, private instruccions, expedicions, how many such has the delay, the hesitacions, the ignorance, or something worse, of Privy Councelors overthrown! Matters maturely advis'd, deliberately concerted, and absolutely resolv'd require but two quallificacions to legitimate their excecucion, (1) that they are legall, (2) really for the publick Good. Such need no Council table to screen them, fear no Parliamentary enquiry, and yet the authors are not answerable for the success. Cabinet Councils in England are modern and excentrick, and I question whether an accion which is not justifyable unless transacted in Council is justify'd by being so in the Cabinet. But Cabinets of ten or fourteen are monsters and useless. If her Majestie leaves the course of things to follow the nature and custome of English Kings, her Privy Council shou'd take cognisance of all needfull affaires, but her Treasurer and Secretary of State should be all her Cabinet, unless she had a well quallifyed Chancelour to add to them. Six sorts of great officers are the moveing springs of the state, and I can not but own without flattery England was never capable of being better supply'd, I do not say is fully supply'd : a Lord Chancelor, a High Admirall, a Generallissimo, a Lord Treasurer, a Secretary of State, an Arch-bishop, who perhaps might expect to be put first, but not by me. Of these the first should be a good lawyer, the second a good sailor, the third a good soldier, the last a good divine. But the Treasurer and the Secretary ought to be good states men. The weight of all the publick attiaires lyes on their shoulders-one for mannageing the revenues, provideing needful funds, maintaining publick credit, and regulateing abuses and exaccions, etc. ; the other for forreign intelligences, correspondence with the courts abroad, mannageing settling and obtaining confederates, observing and suiting affaires with the circumstances and interest of princes.

Intelligence is the soul of all publick bussiness. I have heard that our Secretaryes office is allowed $12000^{1}$ per annum for this weighty article, and I am credibly informed the King of France has paid 11 millions in one year for the same article, and tis allowed be never spares his money on that head, and thereby out does all the world in the knowledge of his neighbours. How much of the $12000^{1}$ allow'd for intelligence is expended in our Secretarys office, I will not guess at; but this I presume, that, such a summe being so vastly disproporcion'd to the necessary expence, the work is not done, and consequently the money that is given for it is lost. Our states men have been so farr from accquainting themselves with other countryes that they are strangers to their own, a certain token that they ha' sought their private advantage not the publick service. The Secretaryes office should be an abrigement of all Europe. Her Majesties Secretary of State ought to have tables of all the following perticulars to referr to, stated so regularly that they might ha' recourse to any perticular imediately. They ought to have, 1st, a perfect 
list of all the gentry and familyes of rank in England, their residences, characters, and interest in the respective countyes ; 2 nd, of all the clergy of England, their benefices, their character and moralls, and the like of the dissenters; 3rd, of all the leading men in the cittyes and burroughs, with the partyes they espouse. They ought to have a table of partyes, and proper callculacions of their strength in every respective part, which is to be had by haveing the coppyes of the polls sent up on all eleccions, and all the circumstances of such eleccions hystorically collected by faithfull hands and transmitted to the office. They should kno' the names of all the men of great personall estates, that they may kno' how and when to direct any occasionall trust; they should have the speciall characters of all the justices of the peace and men of note in every county, to have recourse to on all occasions. Two trusty agents would easily direct all this, so if their hands are not too much tyed up as to money, and yet the persons entrusted not kno' who they serv nor for what end. The Secretary of State should have a table of all the ministers of state, lists of the households, the privy councils, and favourites of every court in Europe, and their characters, with exact lists of their forces, names of the officers, state of their revenue, methods of government, etca., so just and authentick and regularly amended as alteracions happen that by this he may duly estimate their strength, judge of their interests and proceeding, and treat with them accordingly. He should keep a correspondence of friendship in all courts with ministers of like quallity, as far as may be honourably obtain'd and without prejudice carry'd on. Mr. Milton kept a constant epistolary conversacion with severall foreign ministers of state and men of learning abstracted from affaires of state, but so woven with politicall observacions that he found it as usefull as any part of his foreign correspondence. A hundred thousand pounds per annum spent now for 3 year in foreign intelligences might be the best money ever this nacion laid out, and I am persuaded I could name two articles where, if some money had been well apply'd, neither the insurreccion in Hungary nor the warr in Poland should ha' No.4. been so fatall to the confederacy as now they are. If it may be of service, I shall give a scheme for the speedy settleing those two uneasy articles, and consequently bringing down such a force on the French as should in all probability turn the scale of the warr on the Danube and the Po.

A settl'd intelligence in Scotland, a thing strangely neglected there, is without doubt the principall occasion of the present misunderstandings between the two kingdomes; in the last reign it caus'd the King to have many ill things put upon him, and worse are very likely to follow. I beg leave to give a longer scheme of thoughts on that head than is proper here, and a method how the Scotts may be brought to reason. There is a large article of spyes abroad among the enemyes. This I suppose to be settl'd, tho' by our defect of intelligence, methinks it should not; but it reminds me of a book in eight volumes published in London about 7 or 8 yeares ago call'd Letters writ by a Turkish spye. ${ }^{5}$ The books I take as they are a meer romance, but the morall

3 The earliest English edition of this well-known work mentioned by Lowndes appeared in 1691 . 
is good. A settl'd person of sence and penetracion, of dexterity and courage, to reside constantly in Paris, tho,' as 'tis a dangerous post, he had a larger allowance than ordinary, might by one happy turn earn all the money and the charge be well bestowed. There are 3 towns in France where I would hare the like, and they might all correspond, one at Thoulon, one at Brest, one at Dunkirk. They three might trade together as merchants, and the fourth also with them. As intelligence abroad is so considerable, it follows in proporcion that the most usefull thing at home is secrecy; for, as intelligence is the most usefull to us, so keeping our enemyes from intelligence among us is as valluable a head. I have been in the Secretarys office of a post night when, had I been a French spye, I could ha' put in my pockett my Lord N[ottingha]ms letters directed to Sir Geo. Rook and to the Duke of Marlebro' laid carelessly on a table for the doorkeeper to carry to the post. How many miscarriages have happen'd in England for want of silence and secresy! Cardinall Richlieu was the greatest master of this vertue that ener I read of in the world, and, if hystory has not wrong'd him, has sacrifyz'd many a faithfull agent after he had done his duty, that he might be sure he should not be betraid. He kept three offices for the dispatch of his affaires, and one was so private that none was admitted but in the darke, and up a pair of back remote stairs, which office being at the apartments of his niece made room for a censure past upon her character, which the Cardinall chose to suffer, that he might have the liberty to transact affaires there of much more moment. This is a principall reason why I object against bringing all things before the Council, for I will not affirm that the minutes of our Privy Council have not been read in the Secreatryes office at Versailles. Tis plain the French out do us at these two things, secrecy and intelligence, and that we may match them in these points is the design of the proposall.

Further schemes as to trade funds for taxes, etca., relating to the Ld Treasurers share in the public administracion I omitt, haveing taken up too much room with this.

No. 1. What I mean by a step to confirm your friends in the belief of what they hope for from you can not be explain'd without filling your eares with some of those ill-natur'd things they take the freedom to say, viz ${ }^{t}$ that you are a man wholly resolv'd to make your fortunes and to bring it to pass will sacrifize your judgement as well as your friends to your intrest; that you gave proofs of this in embraceing the party of those people who pleas'd themselves and strove to be popular at the expence of King William; that you forsook the king, who treated you kindly, and that his Majestie spoke of it in very moveing terms, as what he was concern'd for; that now you have forsaken the Dissenters and fallen in with their enemyes and promoted the first Occasionall Bill; cum multis aliis, etca. Sir, it is not that I suppose the Dissenters ought to be deciev'd, or that you will deciev them, that I repeat it again, they are to be pleas'd with words. But, Sir, as good words are usefull in their place, so when not spoken with design [they] are honourable in themselves. There is no imediate accion by which you can demonstrate you will serve them. Onely let some proper persons carefully inform them that on all occasions they may depend on your good offices with the Queen, and give them 
some notices by such hands as may be trusted that you are their friend. Perticularly it may be very easy to posess the Dissenters that they owe the change of her Majesties sentiments with relacion to the Occasionall Bill to your mannagement and councils, and that her Majesties changeing sides was, together with the measures you prescrib'd, the onely reason of the majority obtain'd in the House of Lords against the said bill. To effect this a short paper shall be handed about among the Dissenters onely, giveing them a pretended view of the measures taken by some persons, nameing none, to convince the Queen of the unreasonableness of this bill. It can not fail to open their eyes that you are their friend, and yet, if your affaires should require you to disown such a paper, it shall easily be true that you had no knowledge of it, for you may really kno' nothing of it. If my service in another case is accepted, I shall take care to make such a paper be read in all parts of the kingdome. I allow the perticular steps mencion'd in such a paper may not be fact, yet, if it [be] really fact that you have appear'd against the bill, that you bave influenc'd and advis'd her.Majestie in favour of the tolleracion, etca., the generall is truth and therefore the design just. This is part of the perticular step markt No. 1.

No. 2. Of popularity.

That which I call popularity may a little differ from the thing which goes by that name in the generall opinion, and therefore tis needfull to distinguish the term. Popularity in generall is the generall esteem of the people; but the popularity I mean must have an adjunct, vizt. a generall esteem founded on good accions, truly meriting the love of the people. Tis true the people are not so apt to love as to hate, and therefore, when the former is fixt on a person, it ought to implye some merit. But this is not universally true, for the people sometimes love by antithesis, and sho' a generall affeccion for one person to sho' their disesteem of his enemy, and this may be visible in the case of the Duke of Munmouth, who really had not a great deal of personall merit. We say happyness consists in being content; but I must denye it, unless the contentment be fixt on a centre of vertue, for a vicious man may so be more happy than a vertuous, and a mad man than both. So here a man may be popular without merit, but that popularity will neither be usefull nor serviceable :

For tho' by wicked acts men gain applause, The reputacion's rotten, like the cause.

A wise man is willing to be popular, and a wise states man will be so, but it is such a popular esteem as rises from acts of vertue, bounty, and noble principles. Tis my opinion, Sir, as to yourself, and I speak it with the same plaineness as I do things less smooth, that I ought to use more arguments with you to perswade you to desire this popular esteem than to deserv it. And therefore, Sir, I leave the phylosophy of the argument to your own speculacion, and go on to the present case. The popularity I mean now is-a politicall conduct of your self, between the Scylla and the Charibdis of partyes, so as to obtain from them all a generall esteem. Tho this part of conduct is call'd dissimulacion, I am content it shall be call'd what they will, but, as a lye does not consist in the indirect position 
of words but in the design by false speaking to deciev and injure $m y$ neighbour, so dissembling does not consist in putting a different face upon our accions but in the further applying that concealment to the prejudice of the person. For example, I come into a person's chamber who on a surprize is apt to fall into dangerous convulsions; I come in smileing and pleasant, and ask the person to rise and go abroad, or any other such question, and press him to it till I prevail, whereas the truth is I have discovered the house to be on fire, and I act thus for fear of frighting him. Will any man tax me with hypocrisye and dissimulacion? In your perticular post, Sir, you may so govern as that every party shall believ you their own. I think I may answer for one side, and shall think very meanly of my own designs if I do not bring the Dissenters to believ it firmly, if you please to give me leave to act as effectually as I may convince you will be needfull. The Dissenters, Sir, may be brought : 1, To believ better of past accions, of which I mean in the scheme no. 1 ; 2, They shall allwayes believ you their friend with the Queen; 3, Take you for their advocate and applye to you on all occasions; 4, Freely accquaint you of all circumstances relateing to what they desire or fear; 5 , If ever you find occasion, you may be the head of the whole party, and consequently influence them as you please; 6 , You will have the opportunity upon all occasions both to represent them right to the Queen, and the Queen right to them, the want of which has been injurious to both; 7, You will caucion them against indiscrecions, and anything that may be to their disadvantage; 8, You may at second hand accquaint them of the designs of a party against them, and have the honour of saveing them from the mischief intended. The influence your office, as well as personall merit, gives you on the Queen will give you opportunityes either to bring off many of the hott men on the other side or to discourage them that they may cease to disturb; and as to the moderatest of them, you will often by serving them oblige them to acknowlege you. Of the moderate men you are secure, and they can not but both approve your conduct, as they see it moves towards the reall happyness of us all. This is the dissimulacion I recomend, which is not unlike what the Apostle sayes of himself becoming all things to all men, that he might gain some. This hypocrise is a vertue, and by this conduct you shall make yourself popular, you shall be faithfull and usefull to the Sovereign and belov'd by the people. Queen.

No. 3. Of makeing the Secretarys of State an inner cabinett to the

If the Secretarys of State bave a right understanding and act entirely in concert, it will forward it exceedingly. The Secretarys should have a sett of able heads, under a secret management, with whom to make generall callculacions, and from whom to recieve such needfull informacions as by other agents under them may be obtain'd in all necessary or difficult cases, and yet these secret heads need not correspond. From this fund of advice all things needfull to be concerted for the occasions of state may be form'd into schemes and come out perfect. The proposalls made by the Secretarys shall no more be embrios, and be brought before the Council to be argued and amended, but shall be born at once and come before them wholl and compleat, and the Council have 
little to do but to approve a thing as it is proposed. If all the proposalls relateing to publick matters were thus digested, her Majestie would find there was a secret sufficiency some where in her Secretarys office that in time would bring both herself and Council to depend upon the Secretarys of State for all modells of accion, as well as the mannagement, and thus, Sir, I have brought out what I affirm'd at first, that the Secretary of State must of course be Prime Minister. An essay or two of this nature shall be made when you please.

I acknowlege the conjunccion of the Lord Treasurer for the time being would make a compleat conduct, because tis impossible but his Lordship must be furnisht with such helps as may finish things with less difficulty. In this concert all the great accions of state, all orders given to admiralls and generalls, all forreign treatyes, and forreign intelligences, would reciev their last turns, be digested, and finished, and the Queen see herself mistress of the most capitall part of her affaires before they come before the Council. All funds for taxes, wayes and meanes, projects of trade, etca., shall be here form'd into heads, and either be fitted for excecucion or laid aside as impracticable, and my Lord Treasurer be eased of the intolerable impertinence of fund makers and projectors. Secret matters relateing to partyes, to private persons, home mannagement, etca., will here be settl'd, determin'd, and prepar'd for excecucion. Here all the bussiness of the Crown, the affaires of law onely excepted, will center, and the Secretarys office be thus the onely Cabinett. This would make our accions uniform, our councils secret, our orders regular and practicable, and the excecucion punctuall. This would bring the Secretarys office, and above all the Secretary, into such reputacion that orders issued would have more regard, since resentments of missconduct would lye in the breast of the Secretary and be very certain and severe. Here would be a Prime Ministry without a grievance, the people pleas'd, the government serv'd, envy asham'd, intreagues fruitless, enterprizes successfull, and all our measures be both better directed and better excecuted. Att home partyes would be supprest, furious tempers on all sides check't and discountenanc't, peace promoted and union obtain'd. All the leading men of all sides would be influenc'd here, by a rare and secret mannagement; they should never stir nor speak as a party but it should be known. Not a mayor or an alderman in any corporacion, not a shereif of a county, not a member of Parliament or Convocacion, could be elected, but the Government should kno' who to oppose and how to do it, if they saw fitt. This would be the wheel of all publick business, and all the other bussiness must of course depend on the mannagement of this office.

No. 4. Some consideracions with relation to the affaires of Hungaris and Poland.

First, I lay it down as a principle, that the present insurreccion of the Hungarians, be their pretencions never so just, or their provocacions great, the invasion of Poland by the Suede and dethroneing the King, however unjustly he may have acted, are fatall embarrasments to the present confederacy, and in effect great helps to the French in their over runing the Empire and in their attempt on the libertyes of Europe. This being allowed, the wholl confederacy are bound in the consequence to support the Emperor against the Hungarians and the king of Poland against the 
Swedes. If it be objected, why not as well the Swede against the Pole and the Hungarians against the Emperor, since otherwise you fight against the Protestant religion, I return, This is not a war of religion. The present question is not Protestant or Papist, but liberty or universall monarchy; and if it were a war of religion, tis not Protestant or Papist in Hungary and Poland, but in England, Holand and the Empire. Now, if the Hungarian or Swedish Protestants will have so little regard to the interest of the Protestant religion in generall as to make their private share in it clash with the generall, we must do by them as we do by our neighbours when the street is on fire, blow up their houses to save the wholl town. Twould be preposterous temporising, if we should suffer ourselves to be over run for fear of their being ruined. These unfortunate Christians of Hungaria have had the missfortune once before to attempt their liberty in a juncture and in a manner as improper as this, and that was when the Turks came down, or rather when they brought the Turks down, to the siege of Vienna. Now, tho' some people here were so weak to wish the Turks shou'd take the citty because thereby the Protestants would be establish'd, yet no man that could see an hour before him could say but it were better for all the rest of Europe that the Protestants of Hungaria were entyrely rooted out and destroy'd than that the Turks should take the citty of Vienna; and therefore we find the Protestant princes of Germany were the frst and forwardest to march to the relief of it, and the Hungarian Protestants could expect no less. On this account Delenda est. The work must be done; Protestant or Papist, the troubles in Hungary must, if possible, be appeas'd one way or other, and the onely remaining question is how it must, or may rather, be brought to pass. I grant that, as in the simily before, endeavours are allwayes made use of to quench the fire before the blowing up of any houses, so here negociacions should first be attempted and accommodacions propos'd. The Hungarians are without doubt an opprest people, and on the other hand the Emperror is in danger and the juncture favourable. The English and Dutch forming a project of peace and pacificacion and entring into a close imediate treaty on both hands, there is great reason to believ both sides might be brought to see their intrest. First, the reall grievances of the Hungarians to be considered, drawn by way of abstract from Prince Rakocsi's declaracion; and if any mittigacion of demands were tho't reasonable, room left to adjust them by a treaty. Here it may be considred some are capitall articles which must be granted on both sides, as restoreing the Prince, restoreing the free excercise of religion, retrenching the usurpacions of the Romish clergy, calling the assembly of the Estates and leaving them at full and entire liberty to act, withdrawing forreign forces, and the like. On the behalf of the Emperor some capitall articles must be insisted on, such as laying down arms, restoreing towns, delivering magazins, renewing alleigance, and aiding him against the French, and the like. As to matters of taxes, trade, imposts, freedome of passages, bounds of estrtes, and all things relateing to property and civill justice, these may be and must be settled among themselves by treaty or in an assembly of Estates. But for the other an imediate envoy to be sent to the Emperor, or instruccions to the Resident there, as follows : In the name of the wholl confederacy to represent to the Emperor 
the necessity of complying with the Hungarians, and to let him kno' that on these terms peace is both honourable and reasonable, and that, if his Imperiall Majestie will not yield to such a proposall, allowing such alteracions or addicions as are reasonable, they shall think themselves disengag'd from any extraordinary care of the Empire any farther than by treatyes they are bound, and that they will imediately supplye the Hungarians with $1000000^{1}$ sterling to enable them to settle themselves independent of the Empire and establish Prince Rakocsi king of Hungary and Transilvania, and maintain him in the posession of the same. At the same time a faithfull agent to be sent to Prince Rakocsi to represent to him, that, as now be has a favourable opportunity to restore religion and liberty in Hungary, and reestablish himself and his family, so he ought to let his demands be govern'd by the true and just reasons of his takeing up arms, and not build upon the prosperity of his affaires designes which may embark other nacions in a necessary quarrell against him; that they will concern- themselves to mediate with the Empernr such a peace as may secure Hungary against future oppressions, but that, if he pushes on his designes beyond the just demands of reason, they shall be oblig'd to concern themselves against him ; that, as they are ready on the project of peace tendred them to oblige the Emperor to complye with it, so, if not accepted, they have resolv'd to assist the Emperor with 25000 men to be rais'd and maintain'd at their own charge, i.e. the confederates, in order to reduce them by force. These proposalls warmly made, positively insisted on, and resolutely carry'd on, together with a dextrous management, would in all probabillity soon bring the matter to a finall conclusion. It is not sufficient to say this is talking big to no purpose, and is like thunder at a distance, which scares no body, because they are out of the danger, for where will the confederates find 25000 men, etca., for the service. To this I answer, we can find the money, and there's no fear of the men if the money be ready. The Emperor, if be wanted money no more than he wants men, would beat the French out of the Empire in one campaigne. On the other band the Protestants in Hungary want no men, they want onely arms, amunicion, and officers. The last may be supply'd them very well, and money will supply the first with very little difficulty. The advantage of this peace nobody will dispute.

As to Poland, the Swede is now aggressor, and as be was really injur'd by the Pole in an unjust invasion of the Swedish Livonia, yet he ought to be prevail'd with not to carry his private resentments on to affect the present confedracy, of which the king of Poland is a member. When the Swede was embarrast with the Dane, the Muscovite, and the Pole, the English and Dutch interpos'd and gave the king of Danemark the mortificacion of seeing the conquest of Holstien, which was allmost compleat, turn'd upon him and a powerfull army allmost at the gates of Copenhagen. They have the same right and as much reason to restrain the Swede from kindling a war in the bowells of the Empire, which will certainly be the effect of his dethroneing the king of Poland and marching a Swedish army into the Dukedome of Saxony, which appeares now to be the design. How shall this be done? Embassyes and memorialls have been try'd allready, and we do not pretend our envoys in that case 
have been very well treated, haveing been made to follow the Swedish camps and being deny'd audience. One positive memoriall delivred him, with subjoin'd preliminarys of a treaty between the Poles and their king, and between himself and the king of Poland, upon condicions both honourable and advantageous for himself, with a resolucion of the English, the States General, and the king of Danemark, to declare warr against him in case he refuses to treat, would effectually end that warr in two months time. First, I grant the condicions ought to be very good, and very mortifying to the king of Poland, because the Swede was injur'd in the invasion of the subjects. Second, But there is a great difference between demanding satisfaccion of a Prince and setting his own subjects to dethrone him ; there is something more dishonourable in that than in the injury he receivd. But suppose he shall reject the proposall-Act like the French, make the offer with sword drawn, send a strong squadron into the Baltick, not after the ambassador, but with him. If the Swede refuses, assist the Muscovite, let him take the Narva, which he would soon do, if the Swedes are kept from relieving it. This fleet will effectually cut off his comunicacion with his own dominions, expose all Liefland ${ }^{6}$ to the Muscovites, deliver Dantzick from the insults of the Swedes, and force him to complye or be ruin'd. But if it be objected he will joyn with France-If he does, he is undone, France can no way reliev him but by sea, and the confederates will comand the Sound and the passages of the Belt. Here a project for obligeing the Swede by an invasion of Schonen will be to the purpose.

- Livonia. 